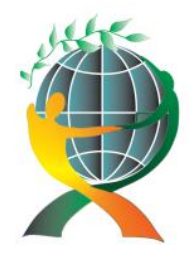

\author{
(online) $=$ ISSN $2285-3642$ \\ ISSN-L = $2285-3642$ \\ Journal of Economic Development, Environment and People \\ Volume 2, Issue 1, 2013 \\ URL: http://jedep.spiruharet.ro \\ e-mail: office jedep@spiruharet.ro
}

\title{
Why society is a complex problem?
}

\section{A review of Philip Ball's book - Meeting Twenty-first Century Challenges with a New Kind of Science}

\author{
Diana Tampu ${ }^{1}$, Carmen Costea ${ }^{2}$ \\ ${ }^{1}$ ASE Bucharest \\ ${ }^{2}$ USH Bucharest
}

\begin{abstract}
The 21st century is burdened by a series of dramatic changes and efforts are carried out to find potential solutions to consumerism, access to information, transient climate disequilibria, health care and demographic transformations. A new page in human history will bear witness to the introduction of new ways of thinking, new changes, new relationships and interconnections that transcend states and societies. The moment is ripe for individuals aware of the implications carried by global changes and challenges, to step up and encourage responsibility and sustainable development. Mankind is currently living in a data-rich world, where information is widely dispersed. Nevertheless, extracting the right assumptions and conclusions from the available data proves difficult as numerous social phenomena do not run with clockwork precision as the laws governing the Newtonian universe.

Human awareness and intelligence demand a more responsible approach to all operations and steps should be made in determining the consequences and their impact. The goal of this paper is not restricted to providing a review but also to enforce certain ideas in relation to the complex interactions specific to society and economic activities.
\end{abstract}

Keywords: multi agent model, complex society, crashes

JEL Codes: H3, D5, G01

- Corresponding author: Diana Tampu, Tel.: + 40.721.566.427;

E-mail address: Diana.tampu@yahoo.com 


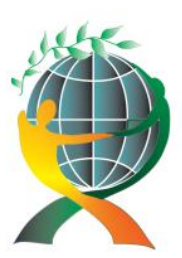

\author{
(online) $=$ ISSN $2285-3642$ \\ ISSN-L = $2285-3642$ \\ Journal of Economic Development, Environment and People \\ Volume 2, Issue 1, 2013 \\ URL: http://jedep.spiruharet.ro \\ e-mail: office jedep@spiruharet.ro
}

\title{
1. Multi agent models and their role in predicting traffic or crowd movements
}

Traffic is one of the simplest systems that can be predicted by treating it as a complex structure. In this way the safety would be improved, pollution would be reduced and millions would be saved from lost working time and inefficiencies of transportation.

When we are in traffic and travel from one place to another, we have only a few expectations: to avoid collisions with other vehicles, to drive at a speed that suits us, and not to flout legal constraints. When we are walking from here to there, the only thing that we want is to avoid collision. All these are possible with the use of very simple agent based models of traffic flow or pedestrian models, like the ones presented in Fig. 1"a" and "b". Researchers have demonstrated that humans tend to follow each other's footstep in public areas because of a psychological impulse.

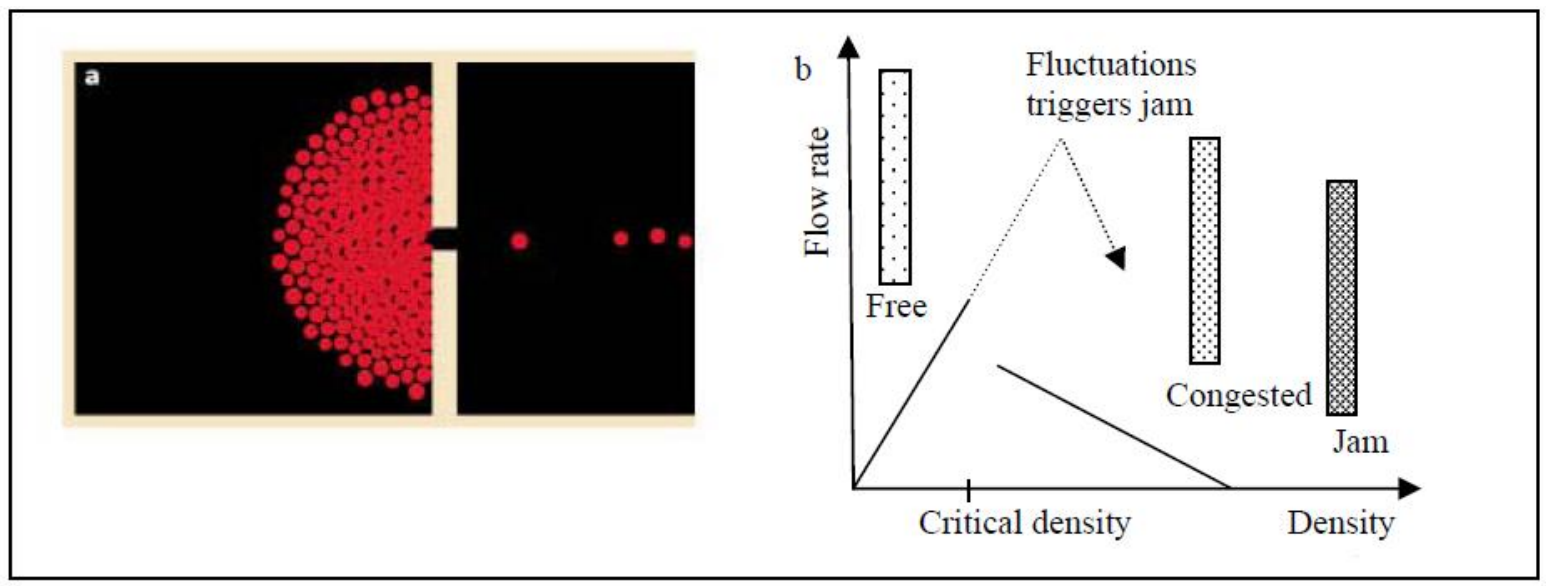

Fig. 1: Agent based model of crowd movement and traffic flow (Ball P., 2012, pp.2, 9)

Fig. 1a, presents the simulation of a crowd trying to exit rapidly from a room in a panic situation, in which individuals escape only slowly and sporadically. Walkers press in against one another in front of the door, trying to move faster. They involuntary form an arch-shaped line and become unable to move forward. Fig. 1b, illustrates an agent-based model of traffic flow assuming that there is a critical density until the flow rate increases steadily. After this point the flow rate stops increasing and abruptly starts to fall, until a traffic bottleneck develops. Both figures present a limit situation, where the actual models aren't efficient in resolving these problems. To have tangible results (the average delays can be reduced by $30-40 \%$ ) in real 


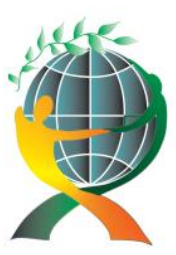

\author{
(online) $=$ ISSN $2285-3642$ \\ ISSN-L = $2285-3642$ \\ Journal of Economic Development, Environment and People \\ Volume 2, Issue 1, 2013 \\ URL: http://jedep.spiruharet.ro \\ e-mail: office jedep@spiruharet.ro
}

time it is necessary to make an innovation that has to be efficient. Winston Churchill (1924) once said: We make our buildings and afterwards they make us. They regulate the course of our lives. Understanding how humans go in public places should enable architects to design them more efficient (Ball P., 2012), as well as the idea of traffic sensors placed before an intersection should give useful information about the traffic density of that area. Nothing could be more real. Schemes like this are already implemented in American cities (Dallas, Texas) and an extension, which could generate a broader vision, is currently considered. In this way the loss of lives caused by uncontrolled movements of crowds during fires, earthquakes, on stadiums or at concerts could be avoided. Sensors implemented in the human body would provide important information about where we are, the speed that we have or direction that we follow. In this way, by using heuristic rules, computer models would enable the buildings to be constructed according to the needs of people, not to adapt people to buildings, roads to be designed in a manner that avoids traffic jams, not to adapt us to the road network. This last argument, for example, influences another phenomenon: robberies. This is dependent on the structure of human environment.

\title{
2. Diseases and epidemics, the spread and control of crimes in a complex society
}

Is not a secret that nowadays all occurrences can be predicted, sometimes very accurately, by statisticians or other scientists. The area of prognosis is very wide, from epidemics to places where robberies and crimes are most frequent. The bell curve - the same curve that describes the variation of birth and death can also forecast the variation of crimes from year to year - because as it has been demonstrated, the crime is not a random or individual act, but a collective social behaviour. The complex systems cannot be guaranteed to answer all the questions of society, but can prove that criminality depends among other things on the establishment of norms, changing demographics, multiculturalism, economic conditions, urban planning and education. In parallel with this, the incidence of burglary is characteristic for terraced houses, not too far from the thief's house.

The current mathematical models in their analysis may not include demographic aspects, or spatial ones, as the above mentioned, but agent based models can include them. Identifying the places where crime has a high level provides the positive effect of increasing the number of law enforcement personnel in that area with the possibility of reducing the number of crimes.

Sociologists James Q. Wilson and Kelling Goerg have shown that people tend to produce antisocial acts when the environment or other people influence them. Thus, the New York subways renounced in 1980 the graffiti designs, and demonstrated that users would behave better when evidence of neglect is removed. 


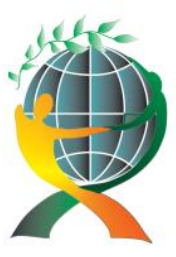

$$
\begin{gathered}
\text { (online) }=\text { ISSN } 2285-3642 \\
\text { ISSN-L }=2285-3642
\end{gathered}
$$

Journal of Economic Development, Environment and People

Volume 2, Issue 1, 2013

URL: http://jedep.spiruharet.ro

e-mail: office jedep@spiruharet.ro

A once result positive, the crime rate decreased and the numbers of violent acts and robberies were cut to 50\% between 1989 and 1999 (Ball P., 2012, pp. 20). The model of crime found in a certain area is similar to the biochemical process thought to produce pigment spots in animal skins (Short M.B., Bratingham P.J., Bertozzi A.L. \& Tita G.E., 2010, pp 107) presented in figure 2.
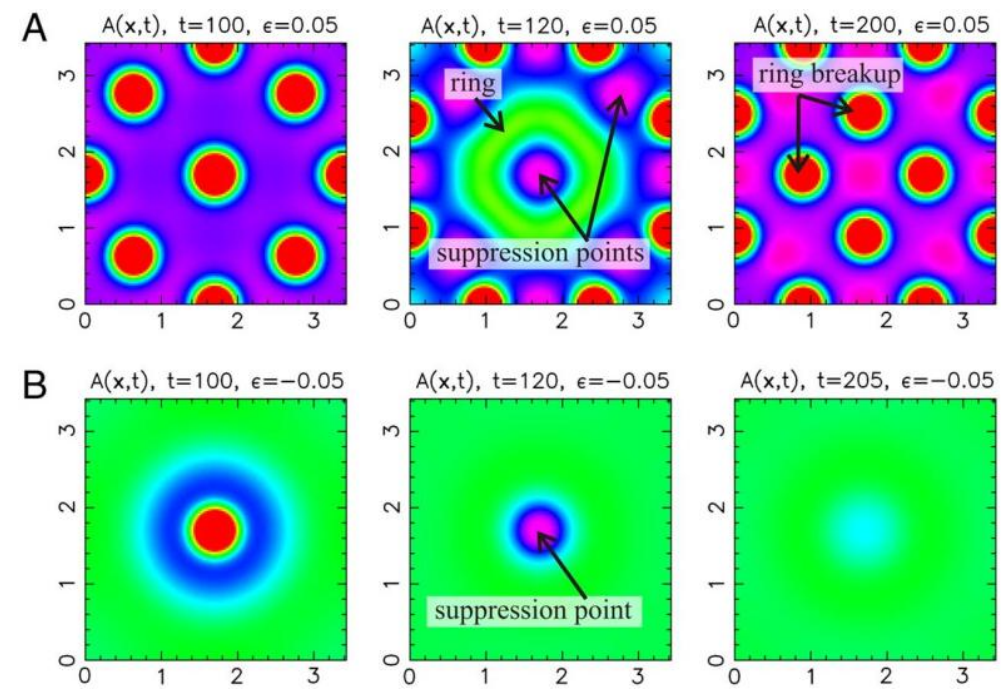

Fig. 2: Interaction of criminals and victims and the similarity with reaction diffusion (Short M.B., Bratingham P.J., Bertozzi A.L. \& Tita G.E., 2010

Crime hotspots presented in Fig. 2 a, can be displaced into a surrounding neighbourhood (the ring situated in the centre in Fig. 2b).

This analysis made available to the competent bodies leads to the concentration of the police officers in problem areas. Although such models have not yet been put into practice, through an empirical approach they can be very useful for law enforcement strategies.

Predictable are not only crimes, but also diseases and epidemics. Transported in ships, airplanes, or in the road network, the transmission of infectious diseases depends on the type of human movement models and the road network described in chapter 1 . 


$$
\begin{gathered}
\text { (online) }=\text { ISSN } 2285-3642 \\
\text { ISSN-L }=2285-3642
\end{gathered}
$$

Journal of Economic Development, Environment and People

Volume 2, Issue 1, 2013

URL: http://jedep.spiruharet.ro

e-mail: office jedep@spiruharet.ro

Society has evolved, and the same is true in the case of viruses and infections. If in 1346 the Bleak Death spread slowly and predictably similar to an ink blot, in 2012 the human crisis crossed the globe in an instance, with the potential for disease epidemics (Balcan D., Colizza V., Goncalves B., 2009) as can be observed in Fig. 3.
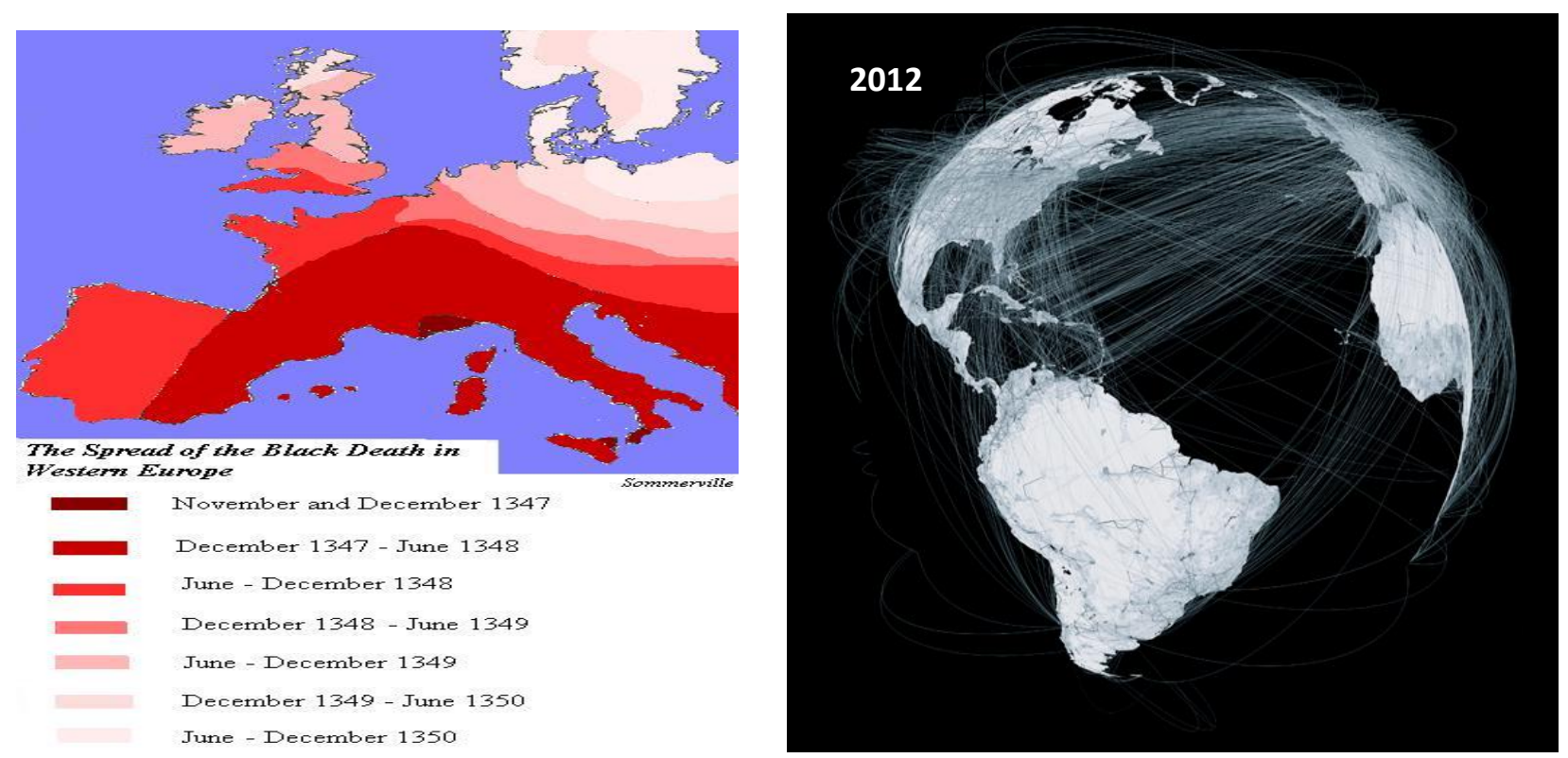

Fig. 3. Year 1346 vs 2012 - the spread of things (Balcan D., et al, 2009, Image courtesy of B. Goncalves, et al./Indiana University)

Today, each of us can cross the globe in less than a day. The increase of human mobility has negative effects on virus transmission such H5N1 (bird flu), H1N1 (swine flu) or other diseases. What at first may seem a regional medical problem; through the transportation network it can become a global pandemic. The solution for combating these infectious diseases is the hubs. Targeting immunization or preventative treatments for key individuals can reduce the chances for the development of an epidemic (Ball P., 2012, pp.30). In this way understanding and predicting the spread of diseases become a multi-dimensional issue. Agent-based model like the Global-Scale Agent Model developed by the Brookings Institution in Washington DC have begun to appear. If in the previous periods we were afraid of viruses, today problems such as increasing obesity in many countries is a better concern. Obese people form clusters in social networks, people tend to borrow from friends habits, research suggesting that a person's chance of becoming obese increases by $57 \%$ if one of his friends is faced with this problem (Ball P., 2012, pp.32). The reasons for this contagion of obesity may underlie several reasons, including: eating habits, increased tolerance of weight 


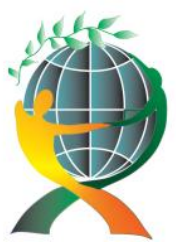

\author{
(online) $=$ ISSN $2285-3642$ \\ ISSN-L = $2285-3642$ \\ Journal of Economic Development, Environment and People \\ Volume 2, Issue 1, 2013 \\ URL: http://jedep.spiruharet.ro \\ e-mail: office jedep@spiruharet.ro
}

gain, psychological effect of imitation, because people are connected, so their health is connected too (Christakis N., Fowler J., 2007).

So the contagion through social networks is also true in case of healthy behaviour. The spread of smoking in the U.S. has decline from $45 \%$ to $21 \%$. A study conveyed (or conducted) over 12,000 people has shown that smokers tend to cluster together. A smoker has $67 \%$ smaller chance of smoking if their spouse quits $25 \%$ smaller if a sibling quits, and $36 \%$ if a friends quits (Christakis N., Fowler J., 2008). To be effective, the anti-smoking campaigns require more targeting relied mostly on clusters and networks.

\title{
3. The network failures and the economic crash
}

The infrastructure of water supply, transport, energy, health and webs of trade and travel that link global airports, seaports, and the social network for friends, associates or businesses do not cover the developed societal needs that exist in our time. None of these networks was designed for the society we live in the present. They are all grown spontaneously after the needs dictated by society. The new view brings in front a dynamic, non-equilibrium system that has constantly changed and adapted to the social needs. As Michael Batty (2008) said planned cities are always the exception rather than the rule and when directly planned, they only remain so for very short periods of time. As indicated in Fig. 4, inter-connectivity is one of the defining and determining features of the modern world.

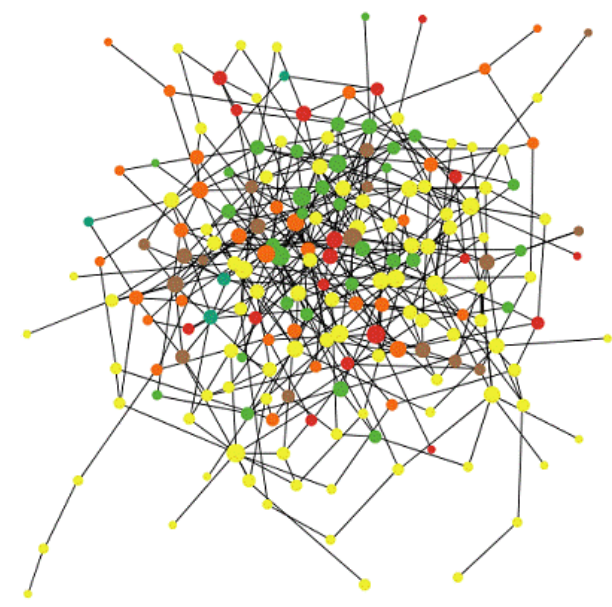

Fig. 4: A random network ( Hawoong Jeong, 2000) 


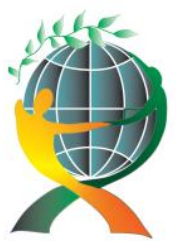

\author{
(online) $=$ ISSN $2285-3642$ \\ ISSN-L = $2285-3642$ \\ Journal of Economic Development, Environment and People \\ Volume 2, Issue 1, 2013 \\ URL: http://jedep.spiruharet.ro \\ e-mail: office jedep@spiruharet.ro
}

Stanley Milgram (1960) has demonstrated that the world has created through the social networking time shortcuts between two points. Thus, appeared the famous six-degree of separation which can be translated into the fact that between any two people, who do not know each other, there are never more than 6 individuals that could make the connection. Similar, any web page is connected to any other by an average of 19 links. This is the principle that Google uses in page ranking schemes, to reflect how good a web page is. These shortcuts have a number of benefits in the real world but when the systems fail they generate crisis.

Economic predictions are notoriously unreliable (Amartya Sen, 1986). On Black Monday the stock market crashed, and like all the previous crashes it came as a surprise to almost everyone. The current models have a missing component that could not predict the unsustainable growth that was encountered in most economies, neither the crisis, which represented the climax. It is not a secret to anyone, that conventional economic theories used in the present by central banks and other economic institutions that inform government policies, fail to anticipate market crashes. The reason is quite simple. These theories and models exclude the presence of such events, the markets being the ones that must adjust themselves. We are still living with traditional patterns of mistakes that not only failed to detect crises, but also cannot offer any kind of comprehensive and effective means of escaping it. The traditional economy is based on several fundamental ideas that in an era of scientific revolution seems to be very simplistic. The physical sciences have passed long ago to models that describe non-equilibrium processes. The latter one argues that since all agents from economy are identical, and that all have access to the same information in the market they take rational decisions that can maximize their profits.

Such concepts should be changed if the global economy, being an immensely complex system, can demonstrate its potential benefits. Agent based models are not a panacea. There is not a general rule according to which a model can be built that is able to guide agents so that crises can be avoided. As stated by Isaac Newton, I can calculate the motion of heavenly bodies but not the madness of people, it is obvious that economic agents aren't rational and the market isn't as efficient as it is thought to be. The alternative to traditional models lies in multi agent models, in which the assumption is that each decision is not identical from one agent to another, price fluctuations are not imposed by exogenous factors but by endogenous ones.

The fluctuations in multi agent models are not similar to the traditional models. If ultimately, the economic fluctuations could be likened to the white noise (see Figure 5a), in reality they tend to have bigger spikes (see Figure 5b). These changes are not related to the changes in the intrinsic value, but are the result of many individual decisions. 


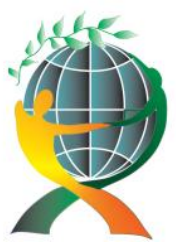

$$
\begin{gathered}
\text { (online) }=\text { ISSN } 2285-3642 \\
\text { ISSN-L }=2285-3642
\end{gathered}
$$

Journal of Economic Development, Environment and People

Volume 2, Issue 1, 2013

URL: http://jedep.spiruharet.ro

e-mail: office jedep@spiruharet.ro

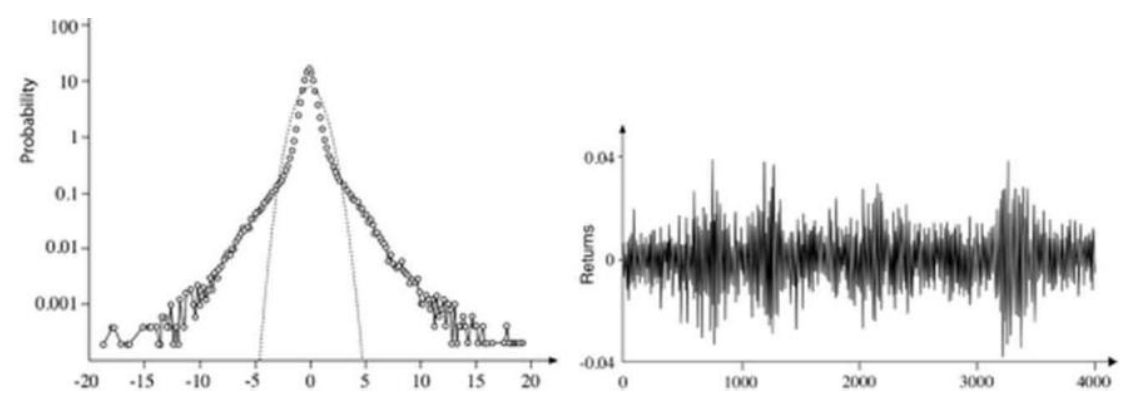

Fig. 5: Traditional models vs multi agent models (Ball P.,2012)

In traditional economies, it was assumed that economic fluctuations tend to have small spikes. The reality is different; in fact they tend to have bigger and large spikes. Because they can accommodate interactions between agents, it is possible to demonstrate the cascades and herding effects that produce the economic bubbles and panics.

Scientists analyse the feasibility of a multi agent model sustainable at national or global level. This would require the knowledge of economic experts in each sector of the economy: labour markets, finance, supply chains, marketing, etc. in order to elaborate basic rules that underlie the decision making of billions of agents, companies and institutions. Between 2006 and 2009, a European team already created a model called Eurace - the largest agent based model created so far. (LeBaron B., Tesfatsion L., 2008). The model, meant to be tested on Greece and Italy's economy will show an appropriate way to deal with massive government debts. The conducted simulations suggest that in the long run economic growth is boosted and unemployment is reduced. If the forecasts are correct, time and agents from the economy are those who shall decide, because better models of our complex society have started to become available.

\section{Conclusions}

Long-term stability and development should represent the pragmatic and realistic objectives for any economy. The present research has demonstrated that only by analysing the society as a complex system, its social and economic issues can be explored and investigated in a fair manner And because society is complex, the problems we are facing are complex too: epidemics and disease, avalanches, traffic jams, crowd panic, criminality, economic crises and financial crashes can be solved only if equations and aesthetic axioms will be replaced with multi-criteria analysis of dates that can cope and best manage our complicated 


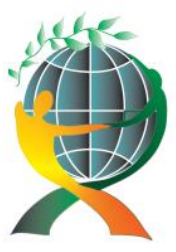

\author{
(online) $=$ ISSN $2285-3642$ \\ ISSN-L = $2285-3642$ \\ Journal of Economic Development, Environment and People \\ Volume 2, Issue 1, 2013 \\ URL: http://jedep.spiruharet.ro \\ e-mail: office jedep@spiruharet.ro
}

and interconnected human world. In order to face all the problems, they cannot be studied in isolation. It is time for a multidisciplinary collaboration between economists and scientists in order to:

- Observe inter-connections between global phenomena and between individuals groups and institutions;

- Create conceptual and technological tools that can handle the actual data-rich society;

- Abandon linear and one -size-fits all thinking;

- Create conditions for effective solutions and not only impose solutions that aren't efficient;

- Discover the advantages of diversity and networking;

- Let organizations to adapt and innovate because this is the future of development;

- Realize that history matters only until multi agent models will be sustainable;

- Offer comprehensive explanations and solutions for social phenomena;

Complex system research on social and economic problems is a very rapidly growing area of scientific enquiry and represents the future.

\title{
5. References
}

[1.] Albert Réka, Hawoong Jeong and Albert-László Barabási, Error and attack tolerance of complex networks, Nature , 2000, 406, 378-382, 2002.

[2.] Balcan D., Colizza V., Goncalves B., Hu H., Ramaso J.J., Multiscale mobility networks and the spatial spreading of infectious disease, Proc. Natl Acad. Sci. USA, 106, 21484-21489, 2009;

[3.] Ball P., Why society is a complex matter. Meeting Twenty - first Century Challenges with a New Kind of Science, Springer; 2012, ISBN-10: 3642289991;

[4.] Batty M., Cities as complex systems: scaling, interactions, networks, dynamics and urban morphologies, Working paper 131, UCL Center for Advanced Spatial Analysis, 2008;

[5.] Christakis N., Fowler J., The collective dynamics of smoking in a large social network, New Engl. J. Med. 358, 22492258, 2008;

[6.] Christakis N., Fowler J., The spread of obesity in a large social network over 32 years, New Engl. J. Med. 357, 370379, 2007;

[7.] Groff E.R., Situating simulation to model human spatio-temporal interactions: an example using crime events, Transactions in Gis 11, 507-530, 2007;

[8.] Kirman A., Complex Economics: Individual and Collective Rationality, Routledge, London, 2011;

[9.] LeBaron B., Tesfatsion L., Modelling macroeconomics as open-ended dynamic systems of interacting agents, Am. Econ. Res. Papers \& Proc., 98, 246-250, 2008; 


\author{
(online) $=$ ISSN $2285-3642$ \\ ISSN-L = $2285-3642$ \\ Journal of Economic Development, Environment and People \\ Volume 2, Issue 1, 2013 \\ URL: http://jedep.spiruharet.ro \\ e-mail: office jedep@spiruharet.ro
}

[10.] Short M.B., Bratingham P.J., Bertozzi A.L. \& Tita G.E., Dissipation and displacement of hotspots in reaction diffusion models of crime, Proc. Natl Acad. Sci. USA, 107, 3961-3965, 2010;

[11.] Vespignani A., The fragility of interdependence, Nature 464, 984-985, 2010; 